\title{
Determining Optimal Public Debt and Debt-Growth Dynamics in the Caribbean
}

\author{
Allan Wright ${ }^{1, *} \&$ Kari Grenade ${ }^{2}$ \\ ${ }^{1}$ Centre for Latin American Monetary Studies, Durango 54, Colonia Roma Norte, Mexico \\ City, Mexico \\ ${ }^{2}$ Caribbean Development Bank, P.O. Box 408, Wildey, Saint Michael, Barbados \\ *Corresponding author: Centre for Latin American Monetary Studies, Durango 54, Colonia \\ Roma Norte. Postal Code 06700, Mexico City, Mexico. Tel: 52-55-5061-6652. E-mail: \\ wright@cemla.org
}

Received: January 30, 2014 Accepted: March 31, 2014 Published: May 4, 2014

doi:10.5296/rae.v6i2.5577 URL: http://dx.doi.org/10.5296/rae.v6i2.5577

\begin{abstract}
This study (i) investigates the debt-growth nexus and the non-linearity issue using panel dynamic ordinary least squares estimations and threshold dynamics in 13 Caribbean countries, (ii) calibrates an optimal debt/GDP ratio for each country using a modified Blanchard (1983) exercise, and (iii) tests the crowding out hypothesis by examining the debt-investment link. The empirical results support the view that there is a non-linear relationship between debt and growth. The findings suggest that there is a global tipping point for the debt/GDP ratio of 61 percent beyond which debt adversely impacts growth and investment. At the country level, the results show marked divergence between actual debt/GDP ratios and the calibrated optimal ratios. The empirical findings have policy relevance for Caribbean countries that are challenged by persistent high debt and low growth in the context where development is financed largely by debt accumulation.
\end{abstract}

Keywords: Optimal Debt, Economic Growth, Investment, Caribbean

JEL Number: C23, F34, H63, O54 


\section{Introduction}

It is widely acknowledged that most developing countries face high debt burdens and the attendant growth and well-being effects are of deepening concern to both researchers and policymakers (Pattillo, et al 2002; Scharlarek and Ramon-Ballester 2005; Reinhart and Rogoff 2010; Kumar and Woo 2010; Cheherita and Rother 2010). A less widely established view is the optimal debt/ gross domestic product (GDP) ratio a country can maintain. In an optimization framework, an optimal debt/GDP ratio is defined as one that maximizes social welfare and economic growth without reducing private investments or increasing sovereign credit risks or raising overall development costs (Blanchard 1983; Stein 2004; Alfaro and Kanczuk 2006; and Rochet 2006). In reality, an optimal debt/GDP can be viewed as one that is consistent with debt sustainability.

In perhaps one of the most influential studies that investigated the debt-growth nexus, Reinhart and Rogoff (2010) found that debt is a drag on growth when the ratio exceeds a 90 percent threshold. In a postwar sample, they found that the average annual growth rate of countries with a debt/GDP ratio above 90 percent drops from 3 percent to -0.1 percent. Reinhart and Rogoff went further and divided countries with debt to GDP ratios above 90 percent into two groups: those below 120 percent and those above 120 percent, showing that those above 120 percent had a lower growth rate. Reinhart and Rogoff's study came under scratching criticism from the economics fraternity when a new study by Herndon et al (2013) found mathematical errors in Reinhart and Rogoff's dataset in trying to replicate their results. Herndon et al reported that in the same postwar sample, average annual growth rate simply eases down from 3 percent to 2.2 percent when the debt to GDP ratio exceeds the 90 percent threshold. Although neither study answered the causality question, the empirical findings of both imply a negative association between debt and growth when debt exceeds a certain threshold. Irrespective of the unsettled causality question, and perhaps the causality question will never truly be answered, concerns about high indebtedness for growth and socioeconomic development more broadly are well placed. This concern is particularly acute in the Caribbean context, where countries are challenged by heavy debt burdens, low economic growth and unacceptably high poverty.

This research is an empirical inquiry into the validity of the debt overhang and the crowding-out theories in 13 Caribbean countries(Note 1). The debt overhang proposition asserts that in the early stages of development, a country needs to boost its capital stock and in turn, economic growth, by borrowing. However, as debt accumulates, resources go to debt servicing, diverting what would have otherwise gone to finance the development needs of the country. The crowding-out view posits that if in the future it is likely that a country's debt stock will exceed repayment capacity, investment is likely to be hindered in anticipation of higher debt service obligations. Specifically, this research refines existing studies on the Caribbean by developing a modified version of Blanchard's (1983) calibration exercise to firstly estimate optimal debt/GDP ratios in the selected countries and benchmark those to actual ones. Secondly, utilizing panel dynamic ordinary least squares (PDOLS) estimations and more recent econometric techniques, the study investigates the debt-growth link, while controlling for debt servicing and a host of empirically-tested growth determinants. Thirdly, 
using threshold dynamics, the study estimates the point beyond which indebtedness becomes inimical to growth. Finally, the study tests the crowding-out hypothesis by explicitly investigating the debt-investment relationship.

Caribbean countries are ideal for examining the important public policy issue of the nexus between public debt and economic growth. Indeed, some Caribbean countries are among the most indebted in the world in terms of debt/GDP ratio. In fact, at the end of 2012, four Caribbean countries (Jamaica, St. Kitts and Nevis, Barbados, and Grenada) ranked among the global top 10 most heavily indebted countries, with an average debt to GDP ratio of 114 percent. Surprisingly, there have been only a handful of studies examining the debt-growth link in the Caribbean. These studies were primarily descriptive and mostly followed a linear approach in investigating the relationship between debt and economic growth without examining optimality with respect to the debt/GDP ratio.

Greenidge et al (2012), which is a welcome enhancement of the eight earlier Caribbean studies, determined a threshold debt/GDP ratio beyond which debt is costly for growth. The salient finding of the study is that debt is not inimical to growth when the ratio to GDP is less than 30 percent, but becomes problematic at ratios exceeding 55-56 percent. However, statistically insignificant results were found at varying debt/GDP thresholds and the impact of debt servicing and total factor productivity (TFP) were not analyzed in the examination of the debt-growth nexus. The main contribution of this study is that it goes beyond the typical examination of debt-growth dynamics that is based on a global threshold debt/GDP ratio. The study, in recognition of the fact that a threshold debt/GDP ratio is not a static notion, calibrates country-specific optimal debt ratio that vary with the macro and financial contexts of countries. Another contribution of this study is that it provides quantifiable estimates of the impact of indebtedness on investment by explicitly investigating the empirical validity of the crowing out hypothesis in the Caribbean. It is noteworthy that this study is not concerned with addressing the causality issue; instead, a critical examination of the nature of the relationship between debt and growth is the focus.

The roadmap for the remainder of this paper is as follows: section two reviews the stylized facts of GDP growth and debt dynamics in the Caribbean. The model and the data are discussed in section three after a brief examination of public debt and growth performances in the selected countries. Estimation results are discussed in section four and section five addresses policy implications. Section six concludes.

\section{Growth and Public Debt Performances in the Caribbean: Snapshot}

Performances in economic growth and public debt in the selected sample of countries have contrasted. While economic growth has been uneven and decelerating, public debt has been accelerating, with persistent expansions in some countries. Table 1 shows the decelerating trend in real GDP growth across countries over the past three decades. The annual simple average rate of growth for the selected countries as a whole moderated to 2.4 percent during 2000-12 from 3.2 percent in both the 1980s and 1990s. The particularly low weighted 
average growth rate during the 1980 s is mainly a result of the economic contractions in Trinidad and Tobago, along with Guyana and Suriname benefitted from fortuitous economic circumstances (high commodity prices) and structural reforms, resulting in a consolidation of growth in the mid-2000s. Growth was interrupted in all of the sample countries in 2009 with the exception of Guyana and Suriname.

Given the external dependence of Caribbean economies, fluctuations in output growth tend to be frequent. The volatility of output growth as measured by the standard deviation of real GDP growth for the sample of countries averaged 1.9 percent during the $1980 \mathrm{~s}, 0.9$ percent during the 1990s, and 2.3 percent during 2000-12. Per capita GDP growth has also been uneven, with a regional annual average of 7.1 percent in $1980 \mathrm{~s}, 2.1$ percent in the $1990 \mathrm{~s}$ and 4.4 percent in the $2000 \mathrm{~s}$.

Table 1. Growth Performance

\begin{tabular}{lcccccc}
\hline & \multicolumn{9}{c}{ Real GDP Growth (\%) } \\
\cline { 2 - 7 } & \multicolumn{2}{c}{$1980-89$} & \multicolumn{2}{c}{$1990-00$} & \multicolumn{2}{c}{$2000-12$} \\
& Average & St. Dev & Average & St. Dev & Average & St. Dev \\
\hline Antigua and & 6.4 & 3.2 & 3.4 & 3.4 & 1.6 & 6.5 \\
Barbuda & & & & & & \\
The Bahamas & 3.5 & 2.9 & 2.7 & 4.9 & 1.2 & 2.5 \\
Barbados & 1.8 & 3.1 & 0.5 & 3.6 & 1.2 & 2.6 \\
Belize & 6.9 & 8.6 & 5.9 & 4.7 & 4.4 & 3.4 \\
Dominica & 5.4 & 4.8 & 2.6 & 1.4 & 1.7 & 3.0 \\
Grenada & 4.1 & 4.1 & 4.4 & 4.0 & 2.3 & 5.2 \\
Guyana & -3.1 & 4.6 & 4.8 & 4.1 & 2.4 & 2.6 \\
Jamaica & 2.3 & 4.2 & 1.3 & 1.9 & 0.8 & 1.7 \\
St. Kitts and Nevis & 5.8 & 4.0 & 4.1 & 1.9 & 2.0 & 4.4 \\
St. Lucia & 6.7 & 5.5 & 3.5 & 3.5 & 1.6 & 3.6 \\
St. Vincent and the & 5.6 & 3.7 & 3.6 & 3.4 & 2.3 & 3.1 \\
Grenadines & & & & & & \\
Suriname & -1.8 & 5.7 & 0.6 & 3.5 & 4.4 & 1.8 \\
Trinidad and Tobago & -1.4 & 6.0 & 3.9 & 3.7 & 5.1 & 5.3 \\
Caribbean & 3.2 & 1.9 & 3.2 & 0.9 & 2.4 & 2.2 \\
\hline
\end{tabular}




\begin{tabular}{lcccccc}
\hline & \multicolumn{7}{c}{ Per Capita GDP Growth (\%) } & & \\
\cline { 2 - 7 } & \multicolumn{2}{c}{$1980-89$} & \multicolumn{2}{c}{$1990-00$} & \multicolumn{2}{c}{$2000-12$} \\
& Average & St. Dev & Average & St. Dev & Average & St. Dev \\
\hline Antigua and & 14.7 & 4.1 & 3.8 & 1.0 & 2.2 & 7.0 \\
Barbuda & & & & & & \\
The Bahamas & 6.6 & 3.3 & 5.7 & 4.7 & 1.2 & 3.8 \\
Barbados & 7.9 & 2.5 & 1.8 & 5.5 & 3.0 & 4.4 \\
Belize & 6.4 & 6.8 & 1.8 & 3.6 & 3.0 & 3.1 \\
Dominica & $\mathrm{N} / \mathrm{a}$ & $\mathrm{N} / \mathrm{a}$ & 5.2 & 4.0 & 3.6 & 4.0 \\
Grenada & 10.0 & 4.3 & 7.5 & 3.2 & 4.3 & 5.5 \\
Guyana & 1.5 & 13.3 & 2.9 & 4.2 & 7.5 & 5.3 \\
Jamaica & 4.2 & 16.0 & 7.7 & 9.1 & 3.8 & 6.1 \\
St. Kitts and Nevis & 14.2 & 6.2 & 9.1 & 11.5 & 2.9 & 6.1 \\
St. Lucia & 11.0 & 9.1 & 7.3 & 4.6 & 3.5 & 5.4 \\
St. Vincent and the & 12.0 & 5.9 & 6.3 & 4.5 & 11.0 & 14.8 \\
Grenadines & & & & & & \\
Suriname & $\mathrm{N} / \mathrm{a}$ & $\mathrm{N} / \mathrm{a}$ & $\mathrm{N} / \mathrm{a}$ & $\mathrm{N} / \mathrm{a}$ & 10.6 & 9.9 \\
Trinidad and Tobago & -2.8 & 14.8 & 2.1 & 12.2 & 11.0 & 14.8 \\
Caribbean & 7.1 & 2.1 & 2.1 & 2.8 & 4.4 & 5.7 \\
\hline
\end{tabular}

Source: Authors' calculations based on data from World Development Indicators, 2012. N/a means unavailable.

Regarding public debt, the combined nominal stock of the selected Caribbean countries was estimated at US\$39.1 billion at end December 2012, a 61 percent increase relative to the stock at end December 2002 (Table 2). At the country level, the elevation in the debt stock has been particularly pronounced in The Bahamas and Barbados, with a more than doubling of the levels within the past decade. Since 2008 and over the recessionary period up to 2010, sustained increases in debt levels have been observed in the majority of countries.

Table 2. Nominal Public Debt (US\$ billion)

\begin{tabular}{lccccccccccc}
\hline & 2002 & 2003 & 2004 & 2005 & 2006 & 2007 & 2008 & 2009 & 2010 & 2011 & 2012 \\
\hline $\begin{array}{l}\text { Antigua and } \\
\text { Barbuda }\end{array}$ & 1.0 & 1.1 & 1.1 & 0.9 & 1.0 & 1.0 & 1.0 & 1.2 & 1.0 & 1.0 & 1.1 \\
The & 1.7 & 1.9 & 2.0 & 2.2 & 2.3 & 2.5 & 2.7 & 3.0 & 3.5 & 3.9 & 4.2 \\
Bahamas & & & & & & & & & & & \\
Barbados & 2.0 & 2.0 & 2.1 & 2.5 & 2.5 & 2.8 & 3.2 & 3.7 & 4.1 & 4.4 & 4.7 \\
Belize & 0.8 & 1.0 & 1.1 & 1.2 & 1.1 & 1.1 & 1.1 & 1.1 & 1.2 & 1.2 & 1.2 \\
Dominica & 0.3 & 0.3 & 0.3 & 0.3 & 0.3 & 0.3 & 0.3 & 0.3 & 0.3 & 0.3 & 0.4 \\
Grenada & 0.4 & 0.5 & 0.6 & 0.6 & 0.7 & 0.7 & 0.7 & 0.8 & 0.8 & 0.8 & 0.9 \\
Guyana & 1.5 & 1.4 & 1.5 & 1.5 & 1.4 & 1.1 & 1.1 & 1.2 & 1.3 & 1.5 & 1.6 \\
Jamaica & 10.3 & 10.4 & 11.3 & 12.2 & 12.9 & 13.3 & 13.8 & 13.7 & 16.4 & 18.2 & 19.0 \\
St. Kitts and & 0.4 & 0.4 & 0.2 & 0.3 & 0.4 & 0.7 & 0.7 & 0.8 & 0.9 & 0.8 & 0.7 \\
Nevis & & & & & & & & & & & \\
\hline
\end{tabular}




\begin{tabular}{lccccccccccc}
\hline St. Lucia & 0.3 & 0.4 & 0.1 & 0.1 & 0.2 & 0.6 & 0.6 & 0.6 & 0.6 & 0.7 & 0.7 \\
$\begin{array}{l}\text { St. Vincent } \\
\text { and the }\end{array}$ & 0.2 & 0.3 & 0.3 & 0.3 & 0.4 & 0.4 & 0.4 & 0.4 & 0.4 & 0.5 & 0.5 \\
$\begin{array}{l}\text { Grenadines } \\
\text { Suriname }\end{array}$ & 0.6 & 0.5 & 0.6 & 0.6 & 0.6 & 0.5 & 0.6 & 0.6 & 0.8 & 1.0 & 1.1 \\
$\begin{array}{l}\text { Trinidad } \\
\text { and Tobago }\end{array}$ & 4.6 & 4.9 & 4.6 & 3.8 & 2.7 & 2.2 & 1.4 & 2.2 & 2.3 & 1.6 & 2.9 \\
Caribbean & 24.2 & 25.2 & 25.9 & 26.6 & 26.5 & 27.2 & 27.5 & 29.6 & 33.8 & 36.0 & 39.1 \\
\hline
\end{tabular}

Source: IMF, World Economic Outlook Database, October 2012.

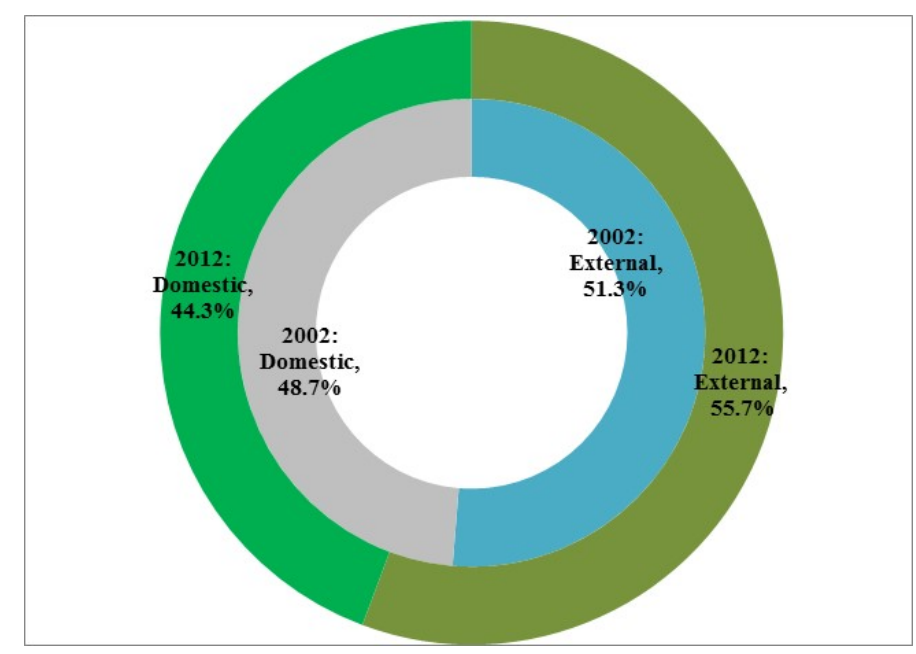

Figure 1. Composition of Public Debt -Caribbean Average (Percent)

On the composition of public debt, Figure 1 shows that the reliance on external debt has increased, from 51.3 percent on average in 2002 to an average of 55.7 percent in 2012, associated with increased reliance on bilateral debt and multilateral financing.

As a ratio of GDP, public debt has been on a steady increase on average at the aggregate level since 2008, reversing the downtrend of the earlier part of the decade (Figure 2). As Table 3 shows, from 2003, persistent reductions in the debt/GDP ratios were recorded in five countries with cumulative percentage points declines as follows: Guyana (71.4); Antigua and Barbuda (48.7); Trinidad and Tobago (33.5); Dominica (27.3); and Suriname (22.6). During the period 2008-12, the debt/GDP ratios increased on aggregate from an average of 68 percent in 2008 to an average of 82 percent in 2012, mainly due to the effects of the global financial crisis. Throughout the decade, The Bahamas, Barbados, St. Kitts and Nevis, St. Lucia and St. Vincent and the Grenadines recorded sustained increases in their debt/GDP ratios at varying intervals during the sample period. A debt decomposition analysis (results not shown for brevity) shows that the main contributors to the increases in the debt/GDP ratios have been modest GDP growth, deteriorating primary deficits and rising interest rates.

The variation between commodity exporting countries and tourism-intensive countries is noteworthy. In the main commodity exporting countries (Belize, Guyana, Suriname, and Trinidad and Tobago) the average debt/GDP ratio in 2012 (50 percent) was 31 percentage points lower than the average ratio at the start of the decade, representing an annual average 
decline of 3.4 percentage points. In the major tourism-intensive countries (Antigua and Barbuda, The Bahamas, Barbados, Dominica, Grenada, Jamaica, St. Kitts and Nevis, St. Lucia, and St. Vincent and the Grenadines), the average debt/GDP ratio increased by 13 percentage points to 97 percent between 2002 and 2012, with a annul average expansion of 2 percentage points.

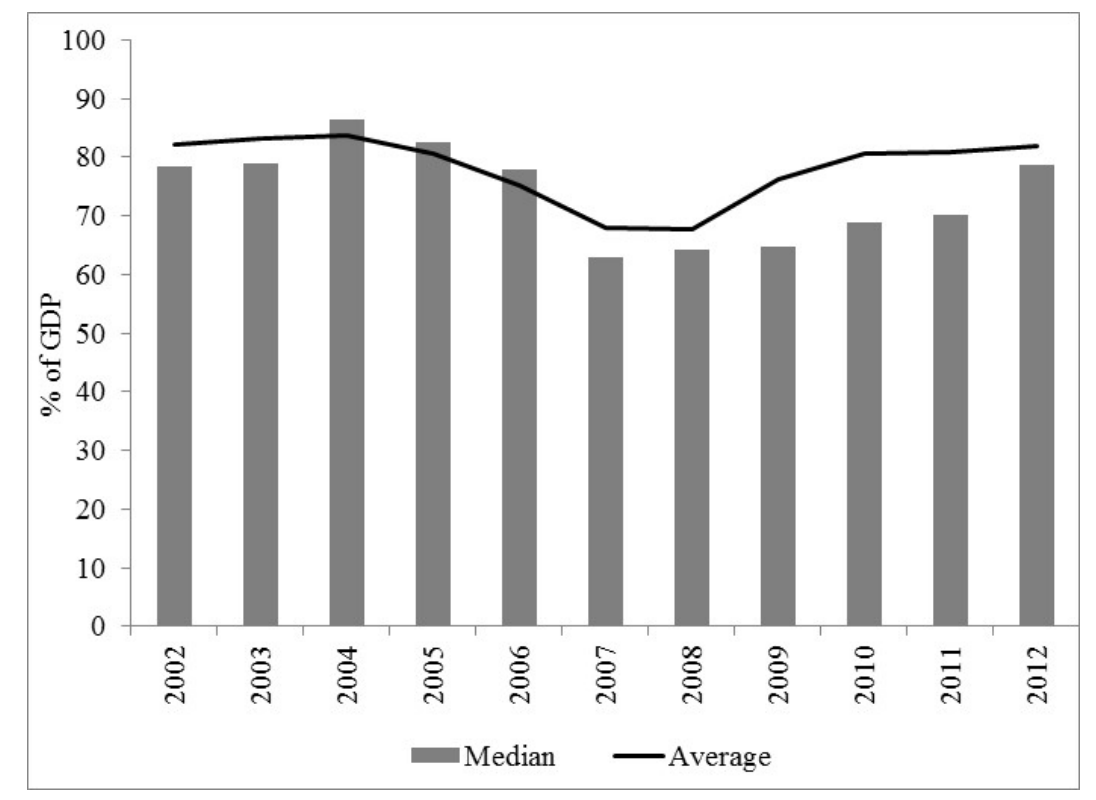

Figure 2. Public Debt - Caribbean

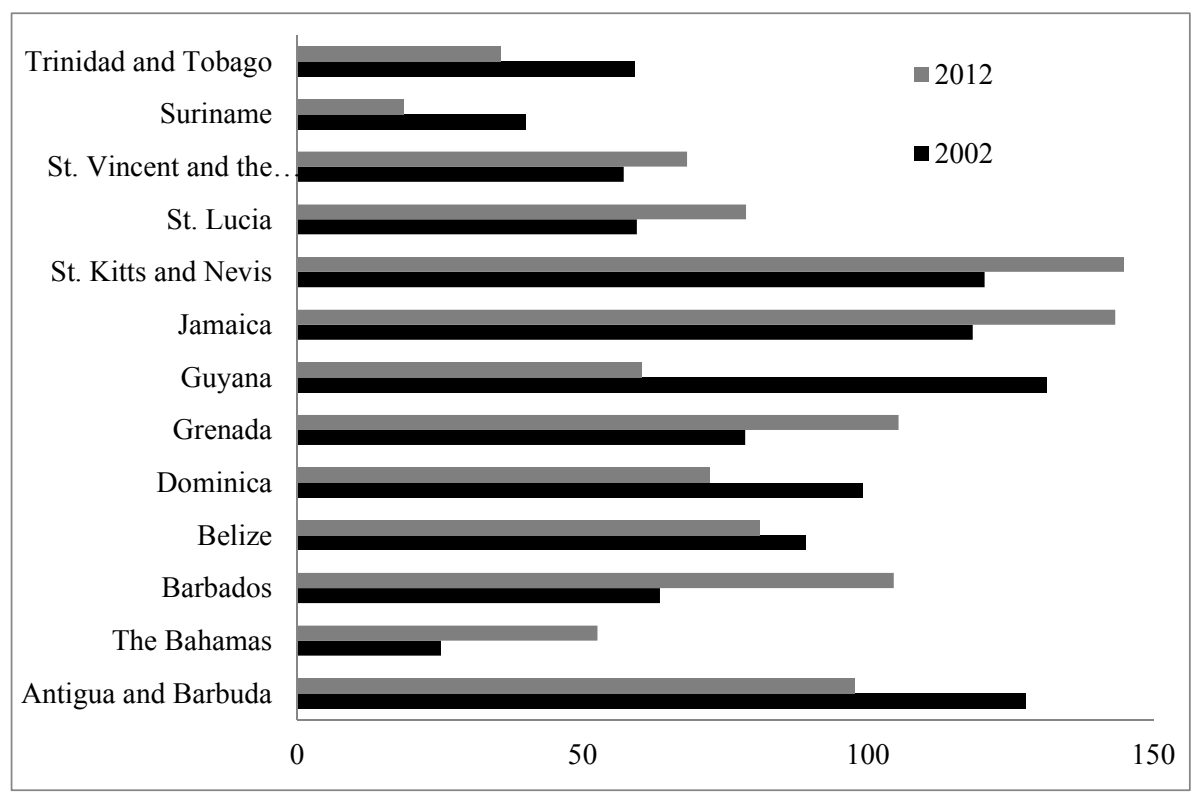

Figure 3. Public Debt-to-GDP (Percent) 
Table 3. Public Debt-to-GDP (Percentage Point Change)

\begin{tabular}{|c|c|c|c|c|c|c|c|c|c|c|c|}
\hline & 2002 & 2003 & 2004 & 2005 & 2006 & 2007 & 2008 & 2009 & 2010 & 2011 & 2012 \\
\hline $\begin{array}{l}\text { Antigua and } \\
\text { Barbuda }\end{array}$ & 14.8 & -1.4 & -4.1 & -27.5 & -4.2 & -11.6 & -1.9 & 25.2 & -11.4 & 2.8 & 4.4 \\
\hline $\begin{array}{l}\text { The } \\
\text { Bahamas }\end{array}$ & 1.0 & 1.6 & 1.8 & 0.5 & 0.2 & 1.4 & 1.8 & 5.5 & 7.3 & 4.0 & 3.1 \\
\hline Barbados & 3.7 & -0.5 & -2.2 & 1.9 & -3.2 & 3.3 & 10.2 & 10.6 & 13.1 & 6.2 & 1.4 \\
\hline Belize & 5.2 & 13.3 & 0.0 & -0.9 & -8.8 & -4.9 & -8.2 & 3.1 & 2.0 & -2.0 & -1.6 \\
\hline Dominica & -1.7 & -3.9 & -8.8 & -3.9 & -4.7 & -5.9 & -7.6 & -1.0 & 5.6 & 1.3 & 2.1 \\
\hline Grenada & 34.1 & 0.3 & 15.4 & -6.2 & 4.5 & -3.7 & -5.2 & 13.4 & 5.3 & 1.3 & 1.7 \\
\hline Guyana & 1.7 & -11.9 & -1.3 & -2.5 & -22.6 & -33.2 & 1.8 & 3.2 & 0.4 & -0.1 & -4.8 \\
\hline Jamaica & 10.4 & 4.7 & -3.2 & -0.6 & -2.3 & -2.3 & 11.4 & 15.0 & 1.8 & -3.0 & 3.4 \\
\hline $\begin{array}{l}\text { St. Kitts and } \\
\text { Nevis }\end{array}$ & 14.7 & 22.7 & 12.8 & 3.9 & -14.6 & -11.3 & -3.0 & 17.5 & 15.4 & -9.5 & -9.4 \\
\hline St. Lucia & 11.8 & -3.3 & 4.5 & 2.3 & -4.0 & -3.6 & 0.9 & 4.2 & 4.8 & 4.5 & 9.0 \\
\hline $\begin{array}{l}\text { St. Vincent } \\
\text { and the } \\
\text { Grenadines }\end{array}$ & 1.0 & 1.7 & 5.1 & 2.5 & -2.8 & -8.1 & 1.4 & 7.8 & 2.0 & 1.3 & 0.2 \\
\hline Suriname & 0.2 & -6.3 & -2.3 & -2.5 & -4.9 & -6.5 & -1.8 & -0.1 & 3.0 & 0.6 & -0.5 \\
\hline $\begin{array}{l}\text { Trinidad } \\
\text { and Tobago }\end{array}$ & 2.6 & -5.9 & -8.0 & -8.3 & -4.3 & -7.0 & -4.0 & 8.6 & 5.0 & -3.4 & 4.0 \\
\hline $\begin{array}{l}\text { Commodity } \\
\text { Exporters }\end{array}$ & 1.5 & -8.0 & -3.9 & -4.5 & -10.6 & -15.6 & -1.4 & 3.9 & 2.8 & -1.0 & -0.4 \\
\hline $\begin{array}{l}\text { Tourism } \\
\text { Exporters }\end{array}$ & 8.6 & 3.2 & 1.9 & -2.5 & -3.6 & -4.3 & 0.0 & 9.2 & 4.2 & 0.6 & 1.3 \\
\hline
\end{tabular}

Source: Authors' calculation based on data from Caribbean Development Bank 2012.

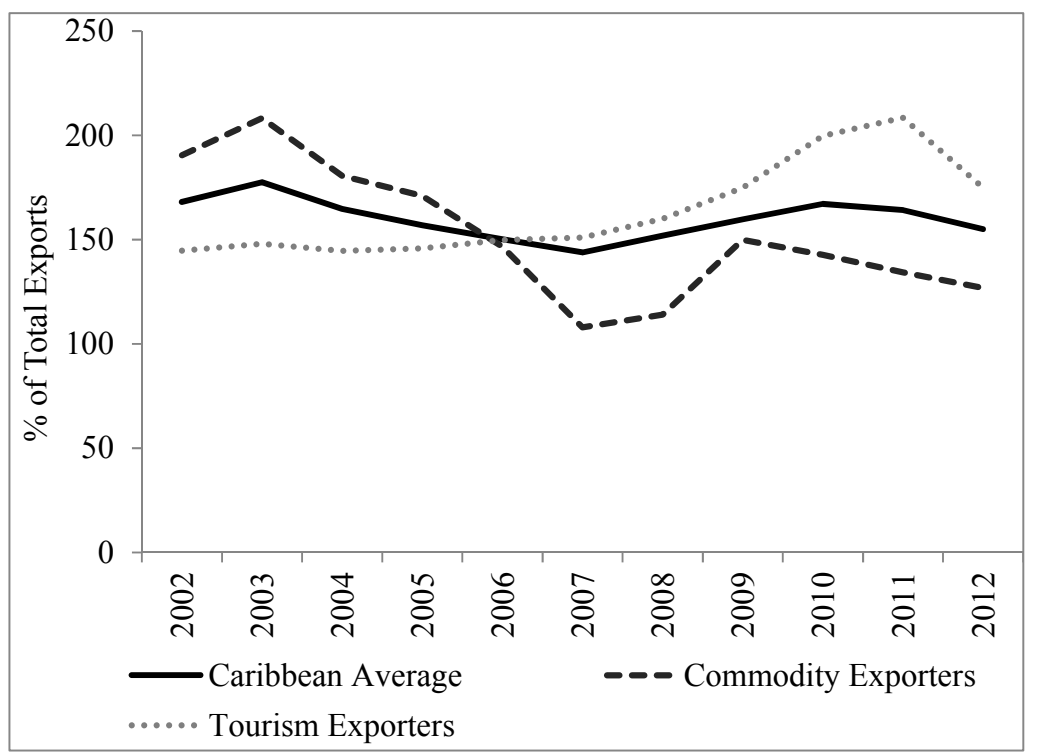

Figure 4. External Debt

(Percent of Total Exports) 
Zeroing in on the external debt burden, as Figure 4 shows, the ratio of total external debt to total exports of goods and services has generally been on a downward trajectory in the commodity exporting countries in the past decade. The ratio fell to an average of 126.8 percent in 2012 from the average of 190.5 percent in 2002, reflecting increased export earnings from rising commodity prices. Contrastingly, in the tourism-dependant countries, the ratio was on a steady uptrend throughout the decade, up until 2011, increasing from an average of 144.8 percent in 2002 to an average of 208.5 percent in 2011 before falling to an average of 174.8 percent in 2012 .

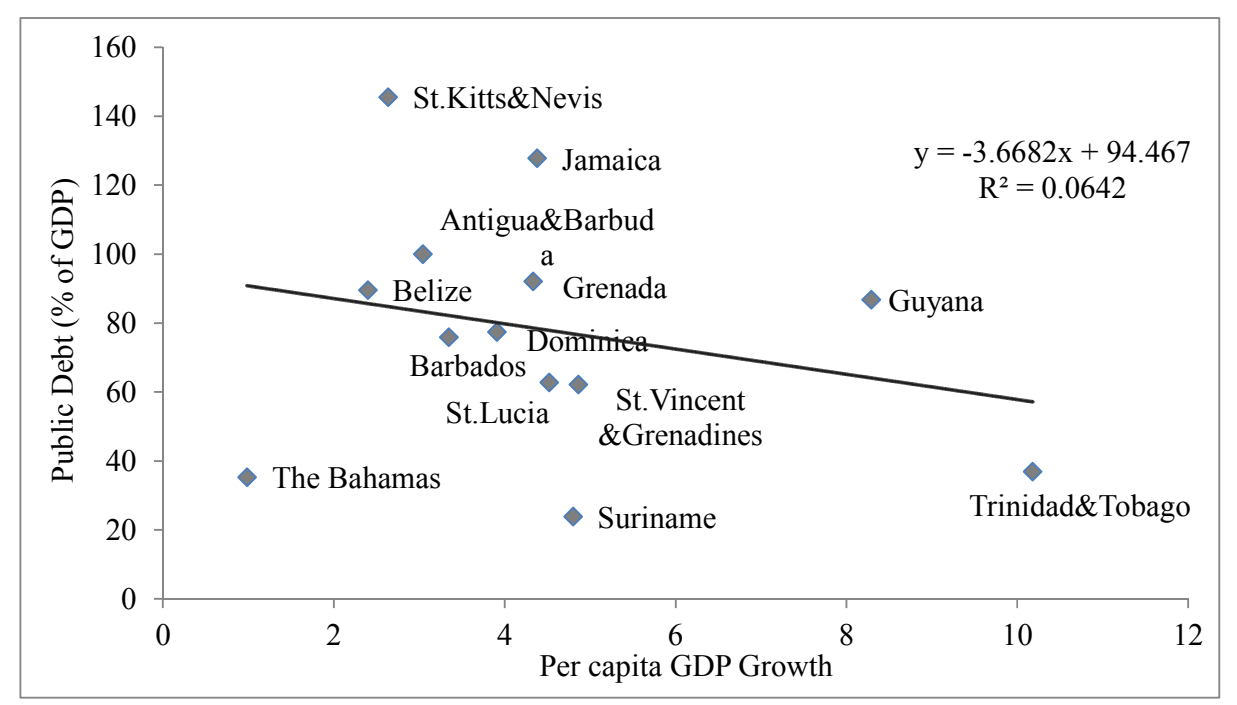

Figure 5. Per capita GDP Growth and Public Debt - Average 2002-2012

Overall, Figure 5 suggests that there is a negative relationship between GDP per capita growth and the ratio of public debt/GDP on average, across the selected Caribbean countries. The majority of countries cluster in the low-growth (2-3 percent) and high-debt (70-100 percent of GDP) ranges. Indeed, there are variations across the Region. Suriname and Trinidad and Tobago distinguish themselves in the high-growth (above 4 percent) and low-debt (below 60 percent of GDP) ranges, while The Bahamas stands out with a low average per capita growth (around 1percent) and low debt burden (less than 60 percent of GDP).

\section{Estimation Models, Econometric Method, and Data}

\subsection{Estimation Models and Econometric Methods}

\subsubsection{The Modified Blanchard Model - Determining Optimal Debt/GDP Ratio}

Blanchard (1983) developed a calibration exercise to solve for optimal debt/GDP ratio given the expected path for capital and net output. In Blanchard's model, the stock of future debt is derived from the existing debt stock and the external current account deficit. The current account deficit includes amounts for debt repayment and the trade deficit of which net output 
is derived. To understand this solution, capital accumulation is first derived following the net output paths, then solutions are derived for total consumption and the external current account deficit, after defining the utility, production, capital accumulation, and adjustment cost functions to be employed (Blanchard 1983). However, the calibration exercise failed to account for changing cost of capital as debt levels rise and the impact of government expenditure (primarily productive spending) on the path of net output. Government expenditure is exogenous. Additionally, the marginal productivity of capital must be greater than the combined growth rates of the population, technology, and the depreciation rate and it must be greater than zero.

The Blanchard model starts with a utility function, defined as: $U=\int_{o}^{\infty} u\left(c_{t}\right) \cdot e^{n t} \cdot e^{-\theta t} d t$,

where $C_{t}=$ consumption at time $\mathrm{t}, \varphi=$ rate of time preference, $e^{n t}=$ population size at time $\mathrm{t}, \theta=r$ is the changing and exogenous interest rate, which is also greater than the population size. The production function is: $Y=F\left(K, L e^{g t}\right)$, where $K=$ capital stock, $g=$ technology growth, $L e^{g t}=$ effective amount of labor input. The adjustment cost function is given by: $I\left[1+\varsigma\left(\frac{I}{K}\right)\right]$ assuming that $\varsigma\left(\frac{i}{k}\right)=\frac{1 i}{2 l k}$, where the change in capital stock is given by $\frac{d K_{t}}{d t}=I_{t}-\delta K_{t}$.

To find the solution, we start solving for capital accumulation, and then solve for consumption and the current account. Given the specifications stated above, we solve for the first order conditions and characterize investment and capital accumulation respectively as:

$$
\begin{gathered}
\frac{d k_{t}}{d t}=\left[l\left(q_{t}-1\right)-(g+n+\delta)\right] k_{t} \\
\frac{d q_{t}}{d t}=(r+\delta) q_{t}-k f^{\prime}\left(k_{t}\right)-\frac{1}{2} l\left(q_{t}-1\right)^{2}
\end{gathered}
$$

where (4) and (5) are differential equations with unknowns, which can be solved independently of the other equations. In the steady state, $\frac{d k_{t}}{d t}=\frac{d q_{t}}{d t}=0$. To analyze the investment and capital dynamics, we linearize (4) and (5) around the steady state to derive output $y_{t}=K f\left(K_{t}\right)$

Next, consumption is solved for with exogenously determined government spending with: 
$c_{t}=r b_{0}+r \int_{0}^{\infty}\left(y_{t}-k_{t}-\theta-\zeta\left(k_{t}, k_{t}\right)\right) e^{-r t} d t$. The trade balance is derived by subtracting consumption, exogenously determined government spending, investment and its residual cost from output: $t b d_{t}=c_{t}+i_{t}+\theta+\varsigma\left(i_{t}, \eta_{t}\right)-y_{t}$. The current account deficit is obtained next by including the country's debt repayments to the existing trade deficit. The debt/GDP ratio evolves from the current debt level plus the external current account deficit. The current account deficit is given by: $c a d_{t}=t b d_{t}+(r-g-n) b_{t}$. The debt/GDP ratio: $b_{t+1}=b_{t}+c a d_{t}$.

Our modified version of Blanchard (1983) model recognizes the exogenous government spending with the calibrated optimal debt/GDP ratio varying on certain country characteristics, such as the initial debt level and the interest rates. For simplicity, we assume that in all countries, the initial actual debt/GDP ratio is equal to the optimal ratio, or along the path toward the optimal ratio, depending on the countries' particular characteristics.

In our calibration exercise, the simulated optimal debts ratios are compared from the same starting point as the actual debt ratios to cover the data period 1990 to 2012.

\subsubsection{Parameters}

The calibrated parameters are set as follows. Technology is set to $v=0.06$, which is similar to that used by Malley (2004) for the country of Ireland, which assumed a Hicks neutral technological progress parameter of 6.095. Mourmouras and Ranzagas (2008) assume the parameter to be 2.27 percent, equal to the average annualized growth rate of labor productivity in 11 developed countries between 1870 and 1990. Fuentes and Mies (2012) assume the parameter to be 2.2 percent, which was the average per capita growth rate in the United States (US) between 1960 and 2006. The population growth rate is set to $\rho=0.01$, which is the same used by Mourmouras and Ranzagas. The depreciation rate is assigned a value of $\delta=0.10$, the same used by Roache (2006) for a group of seven Caribbean countries. The parameter is also similar to the 0.08 used by Hevia and Loayza (2013) and Klenow and Rodriguez-Clare (2005). Other studies assume a lower value ranging between 0.02 and 0.03 , such as Malley and Fuentes and Mies. The capital share of $\mathrm{Y} / \mathrm{K}$ is assumed to be $\alpha=0.25$, similar to the value of 0.2342 used by Malley, although other studies use a slightly higher value within the range of 0.25 and 0.35 . Mourmouras and Ranzagas) assumed $\alpha$ to be a $1 / 3$, and Fuentes and Mies assigned 0.35 for the US economy. Hevia and Loayza also assumed it to be 0.35 for the economy of Sri Lanka, based on an average across countries that Bernanke and Gürkaynak (2002) obtained using adjusted factor payment data. The initial capital is assumed to be 1, which is similar to the 1.314 value used by Hevia and Loayza for Sri Lanka. The parameter in the adjustment cost function is also assumed to be 1 . The steady-state normalized debt is approximated as implied by the Blanchard (1983) exercise and varies in the different Caribbean countries. Interest rates are also country specific. 


\subsubsection{The Debt-Growth Model}

To understand the impact of debt on economic growth in the selected Caribbean countries, an integrated neoclassical growth approach is used. The real per capita growth model employs the factors of production: $L$ as raw labour input, $K$ as capital stock and $H$ as human capital (Clements et al 2003). The marginal contributions of these variables ( L, K, H) to output $\left(Y_{t}\right)$ are expected to decrease as additions in the stock of debt (D) consume a larger portion of economic output. Understanding the impact on economic growth depends not only on TFP proxies but other variables relating to debt servicing capabilities. Increases in debt over time create an overhang and deep uncertainty as countries struggle to match future income streams with contractual debt. Recognizing also that the effects of debt on economic growth would be higher when the indirect effects of capital stock accumulations, government consumption, debt service levels, and openness of these economies are considered, our model adopts proxies for these variables. Debt is expressed as a percentage of GDP for completeness.

The debt-growth model for this study is specified as:

$$
\Delta(X)=\prod X_{t-1}+\sum \alpha \Delta X_{t-1}+\sigma \gamma_{t}+e_{t}
$$

where $(X)=[$ labour input, capital stock, human capital, government consumption, openness, debt service and the debt/GDP ratio] is a data vector explaining the real output relationship with all independent variables. It determines the elasticities of real output with respect to the independent variables by the factor $\gamma_{t}(1-\alpha-\beta)$ as stated by Clements et al (2003). The $\gamma_{t}$ is a vector of deterministic variables and the random term $e_{t}$ is expected to be white noise. This would yield panel estimations.

\subsubsection{The Econometric Method: Debt-Growth Dynamics (Using PDOLS)}

Using the method developed by Kao and Chang (2000) and Mark and Sul (2003), this study uses PDOLS to derive the long and short-run estimates in the debt-growth investigation in the sample of Caribbean countries. Pioneered by Saikkonnen (1991) and generalized by Stock and Watson (1993), the econometrics technique allows for the estimation of a mixture of I(I) and $\mathrm{I}(0)$ variables, is robust in testing small samples, and avoids endogeneity. Normally, when applying PDOLS, the stochastic nature of the variables is tested using procedures developed by (i) Levin, Lin and Chu (LLC) (2002) and Breitung (2002), which both have a common unit root process as the null hypothesis; (ii) Lm, Pesaran and Shin (IPS) (2003) and Augmented Dickey Fuller - Fisher Chi square (ADF), which both have individual unit root processes as the null hypothesis; and (iii) the Hadri z - statistic, which has a null hypothesis 
of no unit root.

Co-integration tests are completed if the variables are non-stationary and usually the residual-based panel and group statistics tests of Pedroni (1999) are applied after the cross sectional dependence and linearity of the variables are examined. Using the cross-section dependence tests developed by Pesaran (2007), where the Augmented Dickey Fuller and standard Dickey Fuller tests are combined with cross section averages of lagged levels and first differences of the series. Recognizing that the growth model is normally non-linear in nature (Greenidge et al 2012), simple tests of non-linearity are carried out using the Wald statistic (Harvey and Leybourne 2007):

$$
\mathrm{W}_{t}=\frac{R S S_{1}-R S S_{0}}{R S S_{0} / T}
$$

where $\mathrm{RSS}^{0}$ and $\mathrm{RSS}^{1}$ are the residual sum of squares from the unrestricted and restricted OLS regressions respectively. Finally, panel dynamic method is used to determine the short and long-run factors influencing economic growth and capital stock accumulation. As annualized data are used in this study, the model begins with two leads and lags on the first difference of the variables in order to obtain a parsimonious representation of the regression equations. Statistically significant variables are retained in the models.

The estimation of the long-run relationship for Equation (1) is based on the following regression:

$$
Y_{t}=\alpha_{0}+\beta X_{t}+\sum_{i=-k}^{k} \phi X_{t-1}^{1}+e_{t}
$$

where $\mathrm{X}$ is a vector of all explanatory variables, $\mathrm{X}^{1}$ is a subset of $\mathrm{I}(1)$ variables of $\mathrm{X}, \beta$ is a vector of long-run coefficients and $e_{t}$ is a well-behaved error term. The leads and lags of the first differenced I(1) regressors are included to deal with the problems of endogeneity and autocorrelation.

To investigate the short-run dynamics, the estimates from Equation (6) are used to derive a general error correction model of the form:

$$
\Delta Y_{t}=\beta_{o}+\sum_{1=1}^{m} \beta_{1_{t}} \Delta Y_{t-1}+\sum_{1=0}^{m} \beta_{2} \Delta X_{t-1}^{1}+\sum_{1=0}^{m} \beta_{3} Z_{t-1}+\sum_{i=1}^{m} \varphi\left(Y_{t-1}-\beta X_{t-1}\right)+\mu
$$

Changes in per capita GDP growth are a function of its past, lagged first difference non-stationary variables $\left(\mathrm{X}^{1}\right)$, lagged stationary variables $(\mathrm{Z})$ and the lagged error correction term. The short-run effects are captured by $\beta_{1}, \beta_{2}$ and $\beta_{3}$ while the rate at which per capita 
GDP readjusts to steady state after disequilibrium has occurred is given by $\varphi$.

\subsubsection{The Threshold Debt Model}

Hansen $(1996,2000)$ developed a methodology to test threshold debt/GDP ratios. The essence of Hansen's method is detailed in Equation 2:

$$
\vartheta_{i t}=\vartheta_{1}\left(1-\eta_{i t}^{D^{*}}\right)\left(D_{i t}-D^{*}\right)+\vartheta_{2} \eta_{i t}^{D^{*}}\left(D_{i t}-D^{*}\right)+\varphi \vartheta_{i t}+e_{i t}
$$

Where $\mathrm{D}^{*}$ is the threshold debt/GDP ratio, $\eta$ is a variable that takes the value of 1 if the debt/GDP ratio exceeds $D^{*}$ and zero otherwise. $D^{*}$ is estimated from the standard errors of each individual parameter, as the coefficient of the estimated debt/GDP ratio turns from positive to negative in a threshold search. $\vartheta$ is the vector of variables that explain the real output relationship and are estimated when the debt is above and below the estimated threshold. The estimation of Equation 2 implies computing the lowest or minimal sequence of residual sum of squares (RSS) for debt thresholds ranging in our data series from the lowest debt/GDP ratio [D $=16$ percent (Suriname) to the high of $\bar{D}=164$ percent (St. Kitts and Nevis)]. Bootstrapping techniques are used to determine the statistical significant levels of the asymptotic distribution of the t-statistic, which is non-standard. Inferences of the impact of debt on per capita growth were developed for the panel and individual countries following Greenidge et al (2012) and Khan and Senhadji (2000).

\subsubsection{The Crowding-Out Effect Model}

To understand the impact of debt on capital stock accumulation or the crowding-out effect, a model is developed that explains the relationship between capital stock and a data vector of variables including, public debt, debt service, TFP proxies (school enrolments and labour force participation), government consumption, and openness. The model is specified as:

$$
\Delta(y)=\prod y_{t-1}+\sum \alpha \Delta y_{t-1}+\sigma \gamma_{t}+e_{t}
$$

where $\left({ }^{y}\right)$ is a data vector of variables that explain the crowding-out relationship. The variables include labour input, real output growth, human capital, fiscal balances, openness, debt service levels and the debt/GDP ratio. The elasticities of capital stock with respect to these variables are determined by the factor $\gamma_{t}\left(1_{-} \alpha-\beta\right)$ as previously stated and again the

$\gamma_{t}$ is a vector of deterministic variables, and the random term $e_{t}$ is expected to be white noise. 


\section{$\Lambda$ Macrothink}

The variables estimated in the model, include net output, capital accumulation, government consumption, TFP variables (including labour participation and human capital proxy) and an openness indicator derived from a measure of both exports and imports. Similar variables are used in our empirical investigations of the debt-growth nexus, threshold dynamics, and crowding out effects in the selected Caribbean countries.

\subsection{Data}

The data used in this paper cover the period 1990 to 2012, for all of the sample countries. Data were obtained from the World Development Indicators, 2012 and IMF's World Economic Outlook Database, October 2012. In testing the debt-growth relationship, the dependent variable is per capita GDP growth $(\mathrm{Y})$ and the independent variables are: debt(Note 2) /GDP ratio (DG); derived estimates of capital stock using the perpetual inventory method (PIM) (Note 3), secondary school enrolment as a proxy for human capital (HK); labour force participation rate (LF); government consumption as a percentage of GDP (GC); openness indicator (OP) (derived from adding export and imports, both expressed as a share of GDP); and debt service ratio (DS) (derived from expressing debt service payments as a share of export of goods and services). Exports of goods and services are used instead of GDP due to the high degree of openness of the economies. When testing for the crowding out effects on investment, the independent variables become the debt variable indicators (DG, DS), Y, K, TFP variables (HK, LF), GC, and OP. Descriptive statistics of the series are shown in Appendix 2. All stochastic, cross dependency, linearity, cointegration and panel threshold test results are available upon request from the authors.

\section{Estimation Results}

\subsection{The Modified Blanchard Model - Determining Optimal Debt Ratios}

The results of the modified calibration exercise show that in Jamaica, Grenada, and St. Kitts and Nevis, the actual debt/GDP ratios are higher than the calibrated optimal ratios (Figures 6-8).

\subsubsection{Jamaica}

In the period 2001-2003, Jamaica's actual debt/GDP ratio started increasing, deviating from its optimal, a possible explanation being the lower tourism receipts following the $9 / 11$ event. Then, in the period from 2004-2007, Jamaica's actual debt/GDP ratio started to slowly decrease, although it was still above the optimal ratio. On average, the actual debt/GDP ratio was 11.3 percentage points above the optimal ratio during 2004-2007. After the economic crisis, which first hit financial markets in 2008 and subsequently impacted the real sector, Jamaica experienced a huge decline in tourism receipts and remittances, which would have influenced the deviation between actual and optimal debt/GDP ratios. 


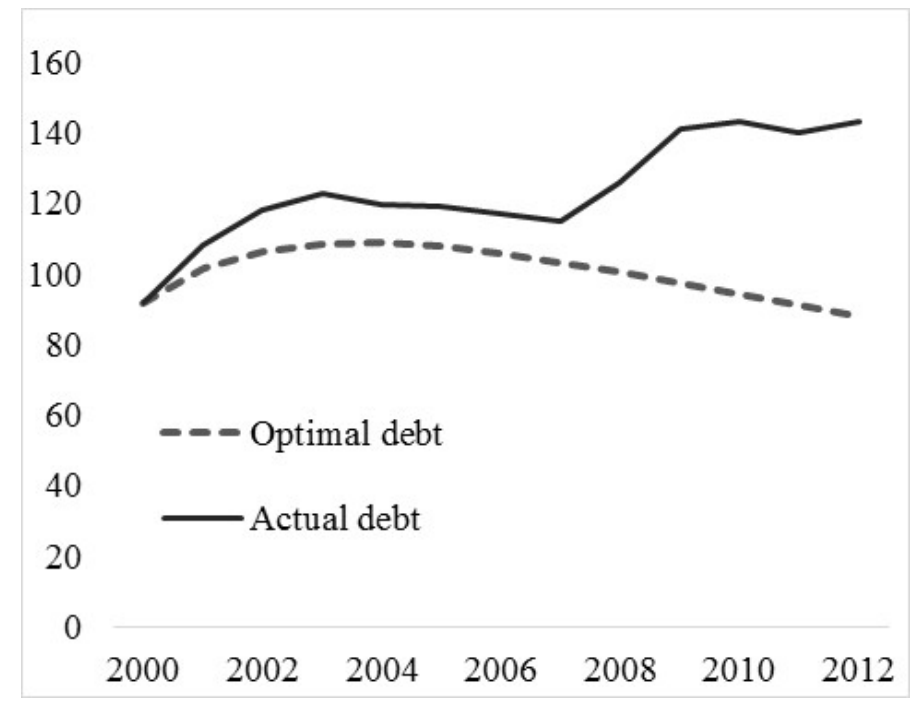

Figure 6. Debt/GDP

Jamaica

(Average, 2002-2012)

\subsubsection{St. Kitts and Nevis(Note 4)}

Starting at a debt/GDP ratio of 97 percent in 2000, St. Kitts and Nevis' optimal debt path suggested a relatively stable path, which should have fluctuated in the narrow range of 104.3 percent and 98 percent in the period 2001-2012. Instead, the country's actual debt/GDP ratio's difference with the optimal ratio has been 37 percentage points, with the largest deviations being in 2005 and 2010. Both of these maximums have probably come as a result of the external shocks that impacted its tourism-intensive economy, first from the $9 / 11$ event in the US in 2001 and then due to the economic crisis of 2009.

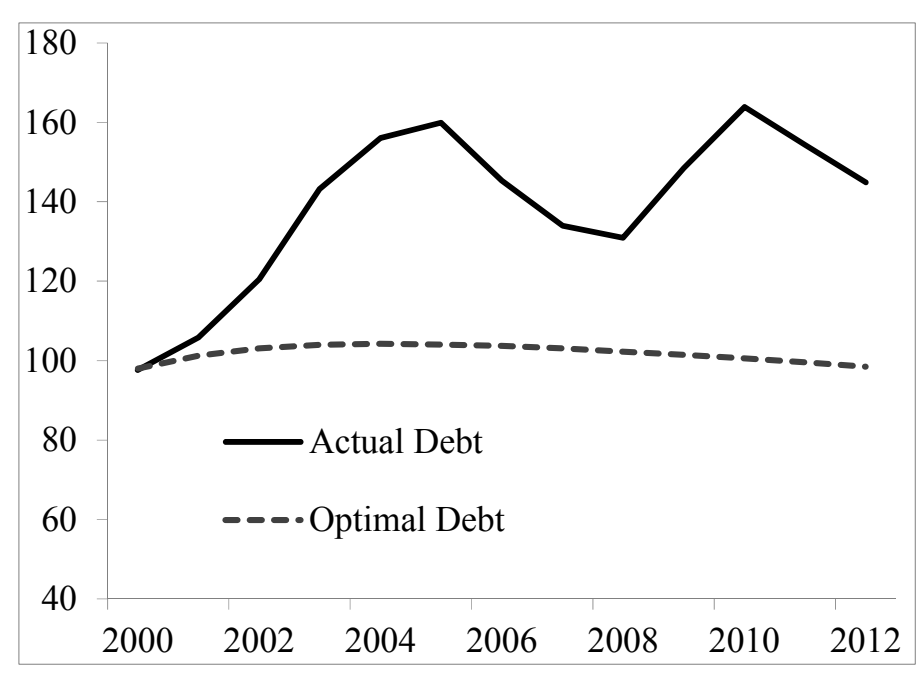

Figure 7. Debt/GDP

St. Kitts and Nevis

(Average, 2002-2012) 


\section{1) Macrothink}

\subsubsection{Grenada}

Grenada started with a much lower debt/GDP ratio of 41 percent. However, the country's debt/GDP ratio has increased above the suggested optimum throughout the years. On average, Grenada's actual debt/GDP ratio has been 13.4 percentage points higher than the optimal, in part due to reconstruction spending from hurricanes Ivan in 2004 and Emily in 2005 and the effects of the economic crisis in 2010.

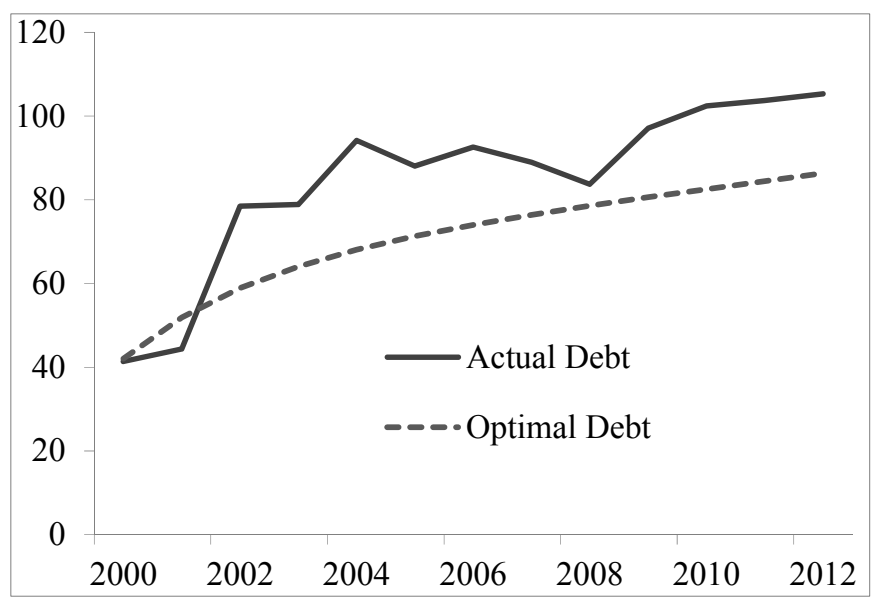

Figure 8. Debt/GDP

Grenada

(Average, 2002-2012)

\subsubsection{Other Countries}

Regarding some of the other countries, in particular: The Bahamas, Belize; Dominica; Guyana; St. Vincent and the Grenadines; Suriname; St. Lucia and Trinidad and Tobago, actual debt/GDP ratios are below their calibrated optimal (Figures 10-21), which is why they are grouped together. An interpretation of this finding is that these countries are perhaps at the moment not facing a solvency issue given relatively lower debt burdens. However, weak growth prospects (except Guyana, Suriname and Trinidad and Tobago) could increase risks of debt distress.

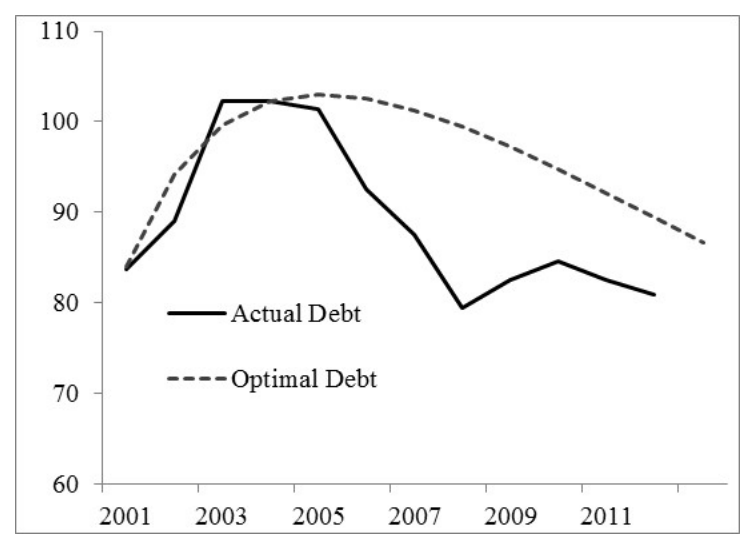

Figure 9. Debt/GDP

Belize

(Average, 2002-2012)

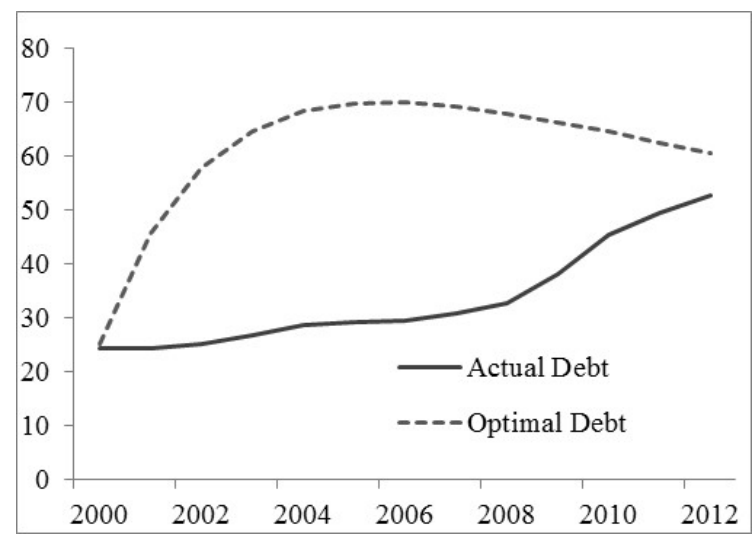

Figure 10. Debt/GDP

The Bahamas

(Average, 2002-2012) 


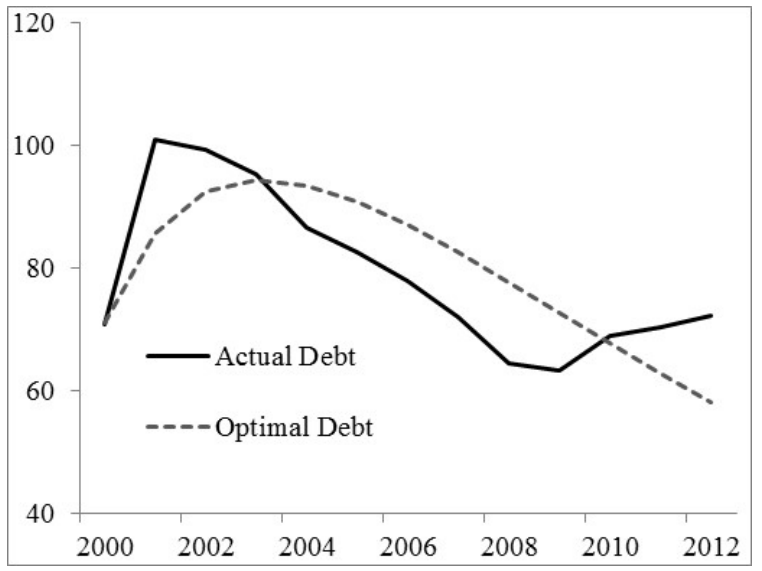

Figure 11. Debt/GDP

Dominica

(Average, 2002-2012)

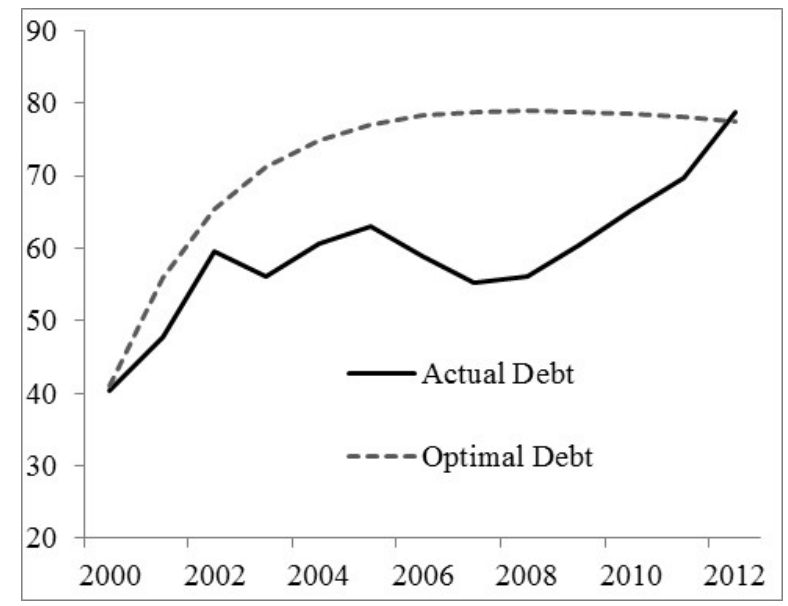

Figure 13. Debt/GDP

St. Lucia

(Average, 2002-2012)

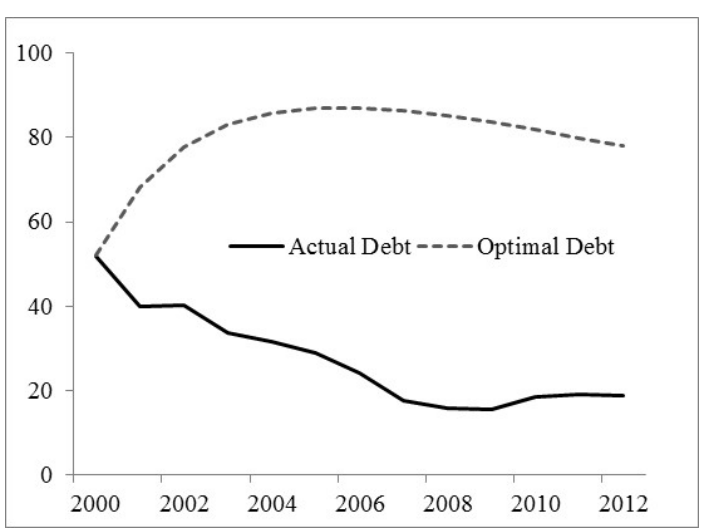

Figure 15. Debt/GDP

Suriname

(Average, 2002-2012)

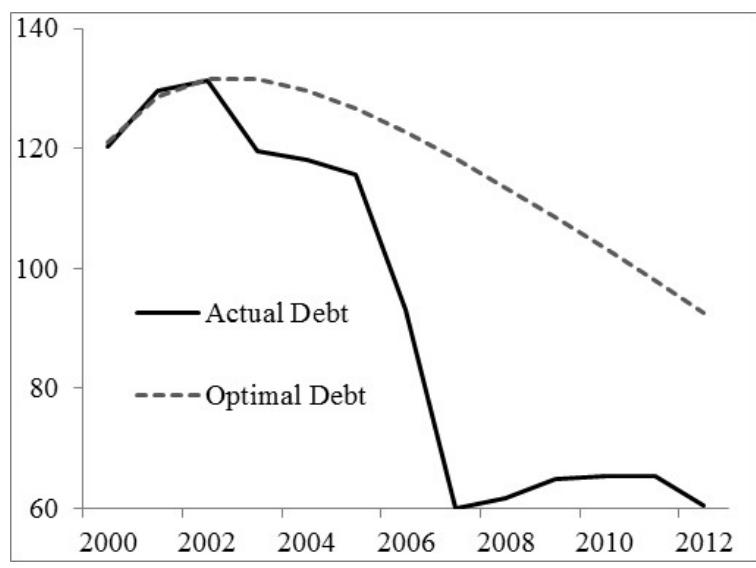

Figure 12. Debt/GDP

Guyana

(Average, 2002-2012)

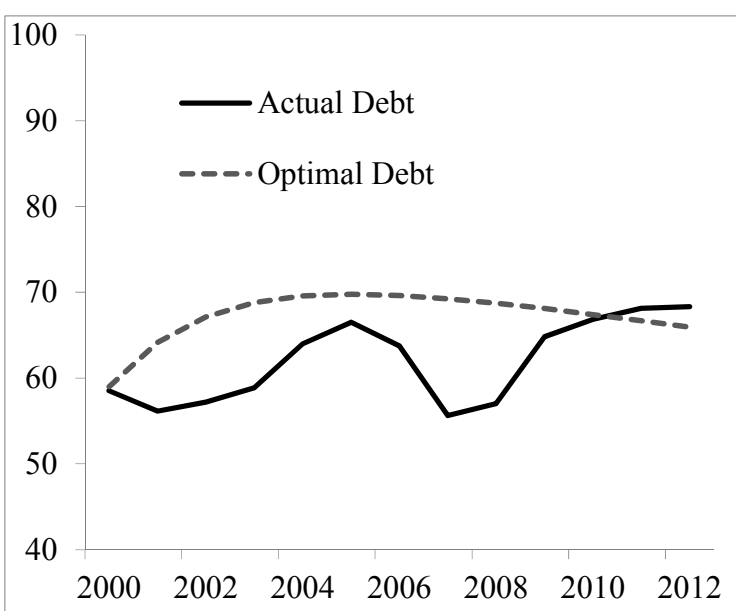

Figure 14. Debt/GDP

St. Vincent and the Grenadines

(Average, 2002-2012)

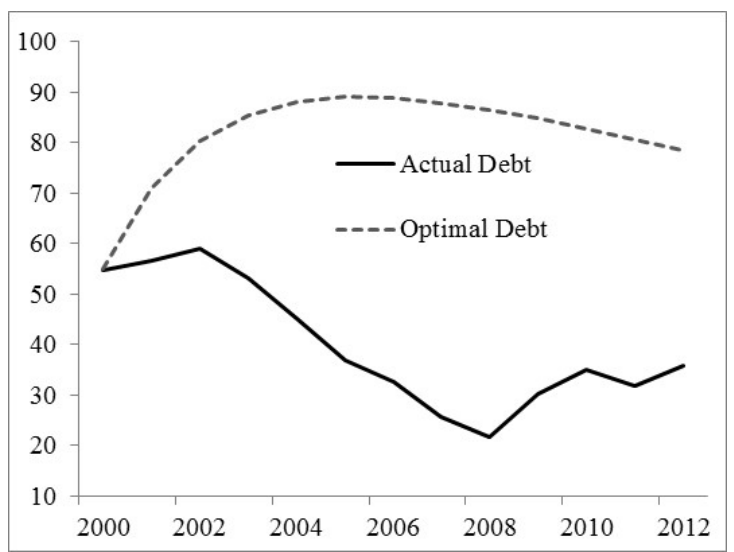

Figure 16. Debt/GDP

Trinidad and Tobago 


\section{Macrothink}

For Antigua and Barbuda and Barbados, the estimated optimal debt/GDP ratios have been above the actual ratios since the onset of the global economic crisis in 2009 (Figures 17 and 18).

\subsubsection{Antigua and Barbuda}

Antigua and Barbuda started with a debt/GDP ratio of 108 percent in 2000. The simulated path for the optimal ratio suggested an initial increase in debt of up to 129 percent of GDP in the early years, followed by a subsequent decrease. In the period 2000-2008, the country's debt/GDP ratio followed more or less this pattern. However, after the economic crisis, the country's actual ratio rose significantly, and by 2012, the actual ratio was already 22 percentage points higher than the optimal ratio, reflecting the decreasing tourism receipts, remittances, FDI inflows, and fiscal revenues.

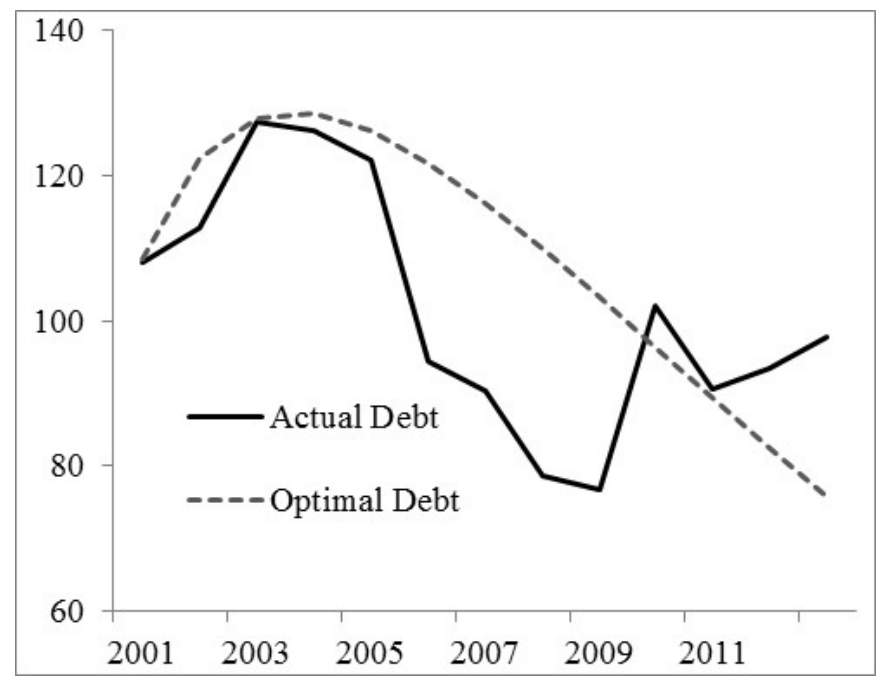

Figure 17. Debt/GDP

Antigua and Barbuda

\subsubsection{Barbados}

In 2000, Barbados had a relatively low debt/GDP ratio of 53 percent, and its optimal path suggested it be gradually increasing throughout the decade. Barbados' actual debt/GDP ratio followed a relatively stable trend, even declining during some years. On average, Barbados' actual debt/GDP ratio was 10 percentage points below the optimal ratio during the period 2000-2009. After the economic crisis, Barbados' debt/ GDP ratio increased drastically, and by 2012 the country's actual ratio was 17 percentage points above the optimal, reflecting acute fiscal deficits resulting from falling public revenues. 


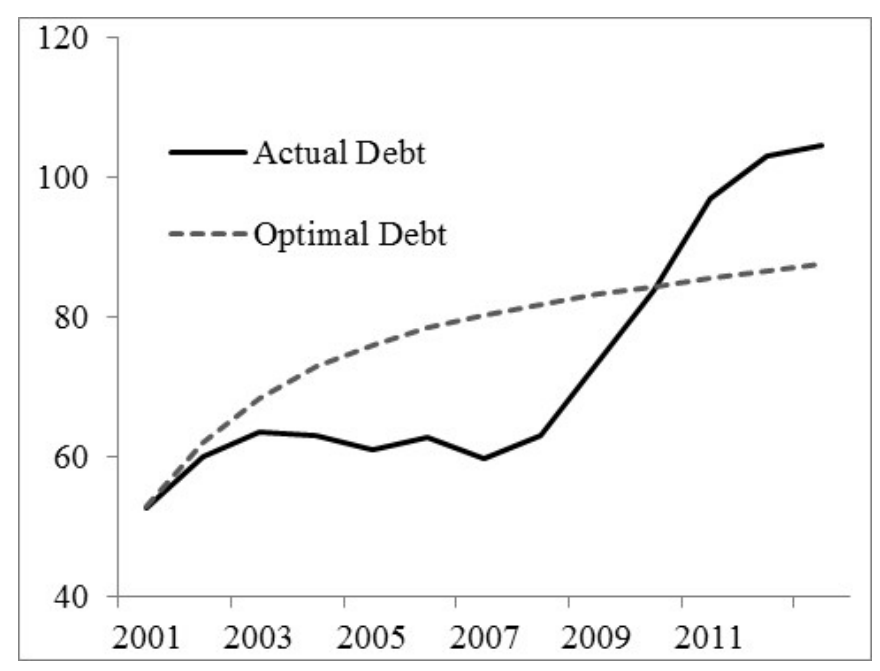

Figure 18. Debt/GDP

Barbados

\subsection{Debt Growth Nexus Approach - Using PDOLS}

The results of the PDOLS estimations show a negative relationship between economic growth and high indebtedness. As shown in Table 4, the estimated coefficients are statistically significant and carry signs that are theoretically and realistically sound. Economic growth is adversely impacted by debt/GDP ratio (-0.25) and debt servicing (-0.146) and positively by gross capital formation proxied by investment as a percentage of GDP (0.18), and the openness indicator (0.27). The model is well specified and shows no evidence of auto-correlation, heteroskedasticity and non-normal residual results. Our findings of a negative debt-growth link are similar those of Greenidge et al (2012) and Clements et al (2003). However, Greenidge et al did not incorporate debt service and TFP variables in the assessment of the debt-growth nexus, and this inclusion is important because it prevents the misspecification of the regression, particularly in these economies which are characterized with high debt service to income ratios.

From the panel results, the negative impact of debt variables on per capita growth was amplified with the inclusion of the openness variable. The government consumption variable and the TFP variables (human capital and labur force participation) were found to be insignificant. These results are not surprising. Previous authors have also indicated that government consumption as a proxy of expenditure is not a long-run contributor to economic growth and is mostly used as a stimulus to short-run economic activity (Kumar and Woo 2010). Regarding the TFP variables, Pattillo et al (2002) argued that for low income countries, such as those in the Caribbean, modest educational attainment as proxied in human capital by secondary school enrolment is not expected to have a significant sustainable impact on economic output neither is size and participation rate of the labour force, as these countries on average traditionally spend a relatively low level of current budget on education and its associated facilities. Beyond trying to rationalise the insignificant finding, the result is perhaps a manifestation of the limitations of small sample size empirics. 
Table 4. Panel Long-Run Coefficients of Real Per Capita Gross Domestic Product

$$
\begin{aligned}
Y_{t}=-0.25 \mathrm{DG}- & -0.146 \mathrm{DS}+0.18 \mathrm{IN}+0.272 \mathrm{OP} \\
\left(-2.95^{* * *}\right) & \left(-2.62^{* * *}\right)\left(2.63^{* * *}\right) \quad\left(4.561^{* * *}\right)
\end{aligned}
$$

Diagnostic Tests:

$$
\begin{array}{llccc}
\mathrm{R}^{2}=0.28 & \overline{R^{2}}=0.263 & \mathrm{~F}=10.51 & \mathrm{DW}=1.95 & \mathrm{NORM}=4.710 \\
\mathrm{AR}=0.235 & \mathrm{ARCH}=0.128 & \text { HET }=0.935 & \mathrm{RESET}=1.62 \\
\hline
\end{array}
$$

Note: $\mathrm{t}$ - statistics of regressors are shown in parentheses.. ***,** and * indicates significance at the 1,5 and 10 percent level of testing, respectively. However, all diagnostics tests are performed at the 5percent level of testing. $\mathrm{R}^{2}$ is the coefficient of determination, $\overline{R^{2}}$ is the coefficient of determination adjusted for degrees of freedom, $\mathrm{F}$ is the F- Statistic for the joint significance of the explanatory variables. DW is the Durbin Watson statistic and the NORM is the test for normality of the residuals based on the Jarque- Bera test statistics. AR is the Lagrange multiplier test for residual autocorrelation and $\mathrm{ARCH}$ is the autoregressive conditional heterscedasticity. HET is the unconditional heteroscedasticity test based on the regression of squared residuals. Finally, RESET = Ramsey test for functional form mis-specification.

The results of the short-run model are reported in Table 5, with the error correction term (ECT) of -0.72; suggesting that it would take real GDP per capita approximately just over one period to return to equilibrium after a shock. The model appears well specified and contains no non-normal results. The short-run or error correction model (ECM) shows that debt/GDP and debt service ratios have a negative impact on real output, a similar result to the long-run findings, while investment, government consumption and labour force participation have a positive impact and openness and the human capital indicators were insignificant in the short-run model.

Table 5. Panel Short-Run Model of Real per capita Gross Domestic Product

$$
\begin{aligned}
& \Delta Y_{t}=-0.349 \Delta \mathrm{DG}-0.1688 \Delta \mathrm{DS}+1.448 \Delta \mathrm{GC}_{t-1} \\
& \left(-3.188^{* * *}\right) \quad\left(-1.755^{*}\right) \quad(4.034 * * *) \\
& 0.1391 \Delta \mathrm{LF}_{t-1}+0.284 \Delta \mathrm{IN}-0.7248 \mathrm{ECT}_{t-1} \\
& \left(2.02^{* *}\right) \quad\left(2.069^{* *}\right) \quad\left(-4.975^{* * *}\right) \\
& \text { Diagnostic Tests: } \\
& \mathrm{R}^{2}=0.429 \overline{R^{2}}=0.411 \quad \mathrm{~F}=113 \quad \mathrm{DW}=2.047 \quad \mathrm{NORM}=3.892 \\
& \mathrm{AR}=1.86 \quad \mathrm{ARCH}=0.65 \quad \mathrm{HET}=0.253 \quad \mathrm{RESET}=1.27
\end{aligned}
$$

Note: $\mathrm{t}$ - statistics of regressors are shown in parentheses.. ***,** and * indicates significance at the 1,5 and 10 percent level of testing, respectively. However, all diagnostics tests are 
performed at the 5percent level of testing. $\Delta$ is the first difference operator. $\mathrm{R}^{2}$ is the coefficient of determination, $\overline{R^{2}}$ is the coefficient of determination adjusted for degrees of freedom, $\mathrm{F}$ is the F- Statistic for the joint significance of the explanatory variables. DW is the Durbin Watson statistic and the NORM is the test for normality of the residuals based on the Jarque- Bera test statistics. AR is the Lagrange multiplier test for residual autocorrelation and $\mathrm{ARCH}$ is the autoregressive conditional heterscedasticity. HET is the unconditional heteroscedasticity test based on the regression of squared residuals. Finally, RESET = Ramsey test for functional form mis-specification.

\subsection{Threshold Debt Dynamics}

Using Equation 2 to calculate the threshold debt/GDP ratio that optimizes the sequence of RSS for the panel of Caribbean countries, the test results (Table 6) show a threshold debt/GDP ratio of 61 percent that is statistically significant.

Table 6. Estimated Threshold Debt/GDP Ratio: Panel

\begin{tabular}{cccccc}
\hline Panel & $\begin{array}{c}\text { Search Range for } \\
\text { Thresholds }\end{array}$ & $\begin{array}{c}\text { Optimal } \\
\text { Threshold } \\
\text { (percent) }\end{array}$ & $\begin{array}{c}\text { Likelihood } \\
\text { Raito }\end{array}$ & $\begin{array}{c}\text { Critical } \\
\text { Value }\end{array}$ & $\begin{array}{c}\text { Significan } \\
\text { ce Level }\end{array}$ \\
\hline $\begin{array}{c}\text { Sample } \\
\text { Countries }\end{array}$ & $\begin{array}{c}\{16,17,18, \\
19, \ldots \ldots ., 164\}\end{array}$ & 61 & 12.72 & 6.94 & 0.0001 \\
\hline
\end{tabular}

The second column provides the range over which the threshold search was done: from the lowest debt/ GDP ratio recorded in the data set of 16 percent (Suriname) in 2009 to 164 percent (St. Kitts and Nevis) in 2010, by increments of 1 percent, which provided approximately 149 panel regressions of Equation 2. The minimization of the RSS vector occurred at the debt/GDP ratio of 61 percent. A global debt/GDP threshold is estimated because degrees of freedom limitation does not allow for the estimation of individual country threshold debt ratios using the PDOLS technique. Hence, the calibration exercise using the modified Blanchard model derives country-specific optimal debt ratios in recognition of the fact that the optimal debt/GDP ratio changes with the macro and financial context of countries. However, the global threshold result is instructive and offers broad insights of what a tipping point for the debt/GDP ratio could be when heterogeneities are eschewed.

The estimation of the confidence region or level around the estimated threshold debt/GDP ratio was done using the likelihood ratio (LR) in Equation 2. If the LR reached or approached the zero level, then the debt/GDP threshold estimate was deemed to be substantially and significantly different from other potential threshold estimates, and the confidence levels with respect to the threshold estimate would be considered high (Hansen 2000). The confidence region for the panel of Caribbean countries was relatively narrow and implied that an acceptably robust threshold estimate. In comparison to other studies conducted on Caribbean countries, Greenidge et al (2012) found a threshold level of 55-56 percent. However, the authors did not include TFP and debt service variables in the assessment of the debt-growth link, while Boamah and Moore (2009) found an external debt threshold of approximately 63 
percent.

The loss in real per capita GDP from the influence of debt variables are inferred from the coefficients in the long-run sustainable equations for each economy (results are available upon request), which estimated losses in real per capita GDP growth once the debt/GDP threshold is reached as shown in Table 7. A negative sign, such as that of Guyana, Suriname, and Trinidad and Tobago, would imply that debt is not having an adverse impact on economic growth in these countries.

Table 7. Inferred Annual Loss in Real per capita GDP Growth beyond Debt Threshold

\begin{tabular}{lr}
\hline Country & $\begin{array}{c}\text { Annual Loss in Real GDP per capita Growth (percentage } \\
\text { points) }\end{array}$ \\
\hline Antigua and Barbuda & 1.36 \\
The Bahamas & 0.78 \\
Barbados & 1.02 \\
Belize & 1.47 \\
Dominica & 1.14 \\
Grenada & 3.18 \\
Guyana & -5.40 \\
Jamaica & 2.85 \\
St. Kitts and Nevis & 2.93 \\
Saint Lucia & 1.78 \\
St. Vincent and the Grenadines & 1.05 \\
Suriname & -5.90 \\
Trinidad and Tobago & -0.40 \\
\hline
\end{tabular}

The results suggest that in Guyana, Suriname, and Trinidad and Tobago real per capita growth has not been adversely given relatively light debt burdens. In 2012, these three countries had debt/ GDP ratios below the estimated threshold for the panel: Guyana 60 percent, Suriname 18 percent, and Trinidad and Tobago 36 percent. Moreover, these economies continue to grow at relatively fast rates in comparison to most of their peers. This appears largely due to the availability of the rich resource-based structure and commodity prices for gold, oil, and lately bauxite/aluminium ore prices. For the remaining countries, the inferred loss in annual real GDP growth range from 0.78 percentage points in The Bahamas to 3.18 percentage points in Grenada. The Bahamas represents an interesting case, since its debt burden is marginally decreasing its growth rate even when its debt/GDP ratio (53 percent) is below the estimated threshold. The optimal debt/GDP ratio of 61 percent is the estimation for the panel of countries, so this might not always coincide or be close to the estimated optimal for the individual country, which in this case is The Bahamas.

\subsection{Crowding Out Effects}

Using PDOLS to check the impact of debt on total investment, the results show (Table 8) that in the long run the variables: debt/GDP ratio; debt service; openness; and real per capita GDP growth are statistically significant. The debt/GDP and debt service ratios both have a negative 
impact on investment beyond the 61percent debt/GDP threshold, supporting the hypothesis of investment being crowded out with increasing indebtedness. The impact of openness and real GDP variables are positive and support the theory that expanding levels of income and greater trade openness are positively correlated to investment levels in developing and emerging economies. The results are somewhat similar to those derived by Clements et al (2003), who found that debt service crowds out investment.

Table 8. Panel Long-Run Coefficients of Investment

\begin{tabular}{c}
\hline $\mathrm{IN}=\quad-0.40 \mathrm{DG}-0.075 \mathrm{DS}+0.105 \mathrm{Y}+0.59$ OP \\
$(-9.65 * * *) \quad(-2.94 * * *)(4.98 * * *)(4.108 * * *)$ \\
\hline
\end{tabular}

Diagnostic Tests:

$$
\begin{aligned}
& \mathrm{R}^{2}=0.345 \quad \overline{R^{2}}=0.339 \quad \mathrm{~F}=15.92 \quad \mathrm{DW}=2.02 \quad \mathrm{NORM}=6.43 \\
& \mathrm{AR}=0.105 \quad \mathrm{ARCH}=0.67 \quad \mathrm{HET}=0.234 \quad \text { RESET }=1.18
\end{aligned}
$$

Note: $\mathrm{t}$ - statistics of regressors are shown in parentheses.. $* * *, * *$ and $*$ indicates significance at the 1,5 and 10 percent level of testing, respectively. However, all diagnostics tests are performed at the 5percent level of testing. $\mathrm{R}^{2}$ is the coefficient of determination, $\overline{R^{2}}$ is the coefficient of determination adjusted for degrees of freedom, F is the F- Statistic for the joint significance of the explanatory variables. DW is the Durbin Watson statistic and the NORM is the test for normality of the residuals based on the Jarque- Bera test statistics. AR is the Lagrange multiplier test for residual autocorrelation and $\mathrm{ARCH}$ is the autoregressive conditional heterscedasticity. HET is the unconditional heteroscedasticity test based on the regression of squared residuals. Finally, RESET $=$ Ramsey test for functional form mis-specification.

The short-run model with a correctly specified ECT of -0.264 , shows that investment is negatively impacted by debt and debt service, but positively by the openness and the human capital indicators.

\section{Policy Implications}

The salient findings of this research have policy implications for Caribbean governments. First, the negative debt-growth relationship reinforces the point that government borrowing must be done not only on terms that are consistent with entrenching debt sustainability, but also on terms that yields growth dividends in the long run. For countries where the actual debt/GDP ratio exceeds or is close to exceeding the calibrated optimal and the estimated threshold, governments must move decisively to address the imperatives of fiscal consolidation and debt reduction, through comprehensive reforms that tackle both expenditure and revenue. For countries where the actual debt/GDP ratio is below the calibrated optimal, the result does not imply that these countries have space to implement 
expansionary fiscal policies, especially given their vulnerabilities (as is the case with the other countries) to external economic shocks and natural events. These vulnerabilities necessitate the pursuit and maintenance of a tight fiscal regime. Indeed, prudent fiscal management should continuously be implemented through the consistent modernization of the public sector and reforms of expenditure control systems, revenue collection and administration methods, and debt management frameworks. Additionally, structural/fiscal reforms that target improvements in budget credibility (both formulation and execution) are also imperative. Pursing prudent fiscal/debt management cannot be limited only to the central government must also include state-owned entities. Specifically, with regards to debt management, most of the countries need to actively pursue endgame options that include one or more of the following: restructuring that entails postponement of amortization payments and/or interest payments relief; debt swaps; full participation for some countries in the MDRI programme; and debt forgiveness. Finally and importantly, reforms aimed at achieving fiscal and debt sustainability must be complemented by policies to enhance national productivity and competiveness and by extension, economic growth.

\section{Conclusion}

Using a modified version of Blanchard's (1983) model the optimal debt/GDP ratio was calculated for individual Caribbean countries, and compared to the actual ratio. The debt/GDP ratio in Jamaica, Grenada and St. Kitts and Nevis were found to be above what the model calibrates as optimal. Additionally, since the global financial crisis and recession of 2009, actual debt/GDP ratios of Antigua and Barbuda and Barbados have been above the calibrated optimal, while the actual debt/GDP ratio of St. Lucia was just at its optimal point. Taken together, a global debt/GDP tipping point of 61 percent was estimated for the sample countries. An empirical inquiry was also carried out to better understand the debt-growth link when taking into account several control variables such as, the external debt service ratio, TFP proxies as well as government spending and openness variables. The results show that the debt variables have a negative impact on economic growth, and this relationship is amplified when the openness indicator is controlled for. In the long-run model, government consumption and the TFP proxies (school enrolment and labour force participation) were not found to be statistically significant. Notwithstanding, the theory of debt overhang was confirmed in the model. The crowding out hypothesis was also investigated and the results show that debt/GDP ratios exceeding the 61 percent threshold have an adverse impact on investment. Findings lend support to the view that there is a negative relationship between debt and growth and that the relationship appears to be nonlinear. Although the causality question still lingers, the findings provide useful insights into the debt-growth dynamics. The study not only contributes to the discourse on the debt problematique in the Caribbean, but also has relevance for policymakers by providing quantifiable estimates of the growth and investment impacts of high indebtedness. The findings can help inform the policy agenda to address the imperatives of fiscal consolidation, debt reduction and growth acceleration. 


\section{References}

Alfaro, L., \& Rakic, P. (2006). Sovereign Debt: Indexation and Maturity. Research Department Publications 4459.

Bernanke, B., \& Gurkaynak, R. (2002). Is Growth Exogenous? Taking Mankiw, Romer, and Weil Seriously. National Bureau of Economic Research Macroeconomics Annual 2001 (pp 11-72).

Blanchard, O. (1983). Debt and the Current Account Deficit in Brazil. Financial Policies and the World Capital Market: The Problem of Latin American Countries (pp. 187-198). National Bureau of Economic Research.

Boamah, D., \& Moore, W. (2009). External Debt and Growth in the Caribbean. Money Affairs, 22(2), 139-157.

Breitung, J. (2002). Non-Parametric Tests for Unit Roots and Co-integration. Journal of Econometrics, 108(2), 343-363. http://dx.doi.org/10.1016/S0304-4076(01)00139-7

Cheherita, C., \& Rother, P. (2010). The Impact of High and Growing Debt on Economic Growth: An Empirical Investigation of the Euro Area. Working Paper Series 1237.

Fuentes, R., \& Mies, V. (2012). Productivity Differences in Developing and Developed Countries: Where are the Bottlenecks? Universidad Católica de Chile.

Greenidge, K., Craigwell, R., Thomas, C., \& Drakes, L. (2012). Threshold Effects of Sovereign Debt: Evidence from the Caribbean. IMF Working Paper WP/12/157.

Hansen, BE. (1996). Inference When a Nuisance Parameter is not Identified under the Null Hypothesis. Econometrica, 64(2), 413-430. http://dx.doi.org/10.2307/2171789

Hansen, BE. (2000). Sample Splitting and Threshold Estimation. Econometrica, 68(3), 575603. http://dx.doi.org/10.1111/1468-0262.00124

Harvey, D., \& Leybourne, S. (2007). Testing for Time Series Linearity. Econometrics Journal, 10(1), 149-165. http://dx.doi.org/10.1111/j.1368-423X.2007.00203.x

Herndon, T., Ash, M., \& Pollin, R. (2013). Does High Public Debt Consistently Stifle Economic Growth? A Critique of Reinhart and Rogoff. Political Economy Research Institute Working Paper 322. Massachusetts.

Hevia, C., \& Loayza, N. (2013). Saving and Growth in Sri Lanka. World Bank Policy Research Working Paper 6300.

International Monetary Fund. (2012). World Economic Outlook Database. Retrieved from http://www.imf.org/external/pubs/ft/weo/2012/update/02/

Jarque, C. M., \& Bera, A. K. (1980). Efficient Tests for Normality, Heteroskedasticity and Serial Independence of Regression Results. Economic Letter, 6(6), 253-259.

Kao, C., \& Chiang, M. (2000). On The Estimation and Inference of A Co-integrated 
Regression in Panel Data. Advances in Econometrics, 15, 179-222. http://dx.doi.org/10.1016/S0731-9053(00)15007-8

Khan, M., \& Senhadji, A. (2000). Threshold Effects in the Relationship between Inflation and Growth. IMF Working Paper 00/110.

Klenow, P., \& Rodriguez-Clare, A. (2005). Externalities and Growth. Handbook of Economic Growth (pp 817-861). http://dx.doi.org/10.1016/S1574-0684(05)01011-7

Kumar, M., \& Woo, J. (2010). Public Debt and Growth. IMF Working Paper WP/10/74.

Levin, A., Lin, Chien-Fu., \& Chu, J. (2002). Unit Root Tests in Panel Data: Asymptotic and Finite-Sample Properties. Journal of Econometrics, 108(1), 1-24. http://dx.doi.org/10.1016/S0304-4076(01)00098-7

Lm, K.S., Pesaran, M. H., \& Shin, Y. (2003). Testing for Units Roots in Heterogeneous Panels. Journal of Econometrics, 115(1), 53-74. http://dx.doi.org/10.1016/S0304-4076(03)00092-7

Maddala, G. Wu, S. (1999). A Comparative Study of Unit Root Tests with Panel Data and A New Simple Test. Oxford Bulletin of Economics and Statistics, 61(1), 631-652. http://dx.doi.org/10.1111/1468-0084.61.s1.13

Malley, J. (2004). Lecture Notes on the Theory, Calibration, \& Estimation of Dynamic Stochastic General Equilibrium Models. Department of Economics University of Glasgow.

Mark, N., \& Sul, D. (2003). Co-integration Vector Estimation by Panel DOLS and Long-run Money Demand. Oxford Bulletin of Economics and Statistics, 65(5), 655-80. http://dx.doi.org/10.1111/j.1468-0084.2003.00066.x

Mourmouras, A., \& Ranzagas, P. (2008). Fiscal Policy and Economic Development. IMF Working Paper 08/155. http://dx.doi.org/10.5089/9781451870138.001

Pattillo, C. A., Ward, H., \& Ricci, L. A. (2002). External Debt and Growth. IMF Working Paper, 02/69. http://ssrn.com/abstract $=879569$

Pedroni, P. (1999). Critical Values for Co-Integration Tests in Heterogeneous Panels with Multiple Regressors. Oxford Bulletin of Economics and Statistics, 61, 653-670. http://dx.doi.org/10.1111/1468-0084.61.s1.14

Pesaran, M. H. (2007). A Simple Panel Unit Root Test in The Presence of Cross-Section Dependence. Journal of Applied Econometrics, 22(2), 265-312. http://dx.doi.org/10.1002/jae.951

Reinhart, C., \& Rogoff, K. (2010). Growth in a Time of Debt. American Economic Review: Papers \& Proceedings, 100(2), 1-9. http://dx.doi.org/10.1257/aer.100.2.573

Roache, S. (2006). Domestic Investment and the Cost of Capital in the Caribbean. IMF Working Paper 06/152. http://dx.doi.org/10.5089/9781451864120.001 
Rochet, J. C. (2006). Optimal Sovereign Debt: An Analytical Approach. Research Department Publication 478.

Saikkonnen, P. (1991). Asymptotically Efficient Estimation of Co-integration Regressions. Economic Theory, 7(1), 1-21. http://dx.doi.org/10.1017/S0266466600004217

Schclarek, A., \& Ramon-Ballester, F. (2005). External Debt and Economic Growth in Latin America. Working Paper. Department of Economics, Lund University.

Stein, J. L. (2004). Optimal Debt and Equilibrium Exchange Rates in a Stochastic Environment: An Overview. CESifo Working Paper 1363, CESifo Group Munich.

Stock, J. H., \& Watson, M. W. (1993). A Simple Estimator of Co-integrating Vectors in Higher Order Integrated Systems. Econometrica, 61(4), 783-820. http://dx.doi.org/10.2307/2951763

World Bank. (2012). Development Indicators. Retrieved from http://data.worldbank.org/data-catalog/world-development-indicators

\section{Notes}

Note 1. Antigua and Barbuda, The Bahamas, Barbados, Belize, Dominica, Grenada, Guyana, Jamaica, St. Kitts and Nevis, St. Lucia, St. Vincent and the Grenadines, Suriname, and Trinidad and Tobago.

Note 2. Total debt (central government plus contingent liabilities).

Note 3. Capital stock data are derived from gross investment flows multiplied by an assumed depreciation rate of 10 percent.

Note 4. Debt data used in this study are prior to the revised data published following St Kitts and Nevis' debt restructuring in 2011. 
Appendix

Appendix 1: Descriptive Statistics of Series

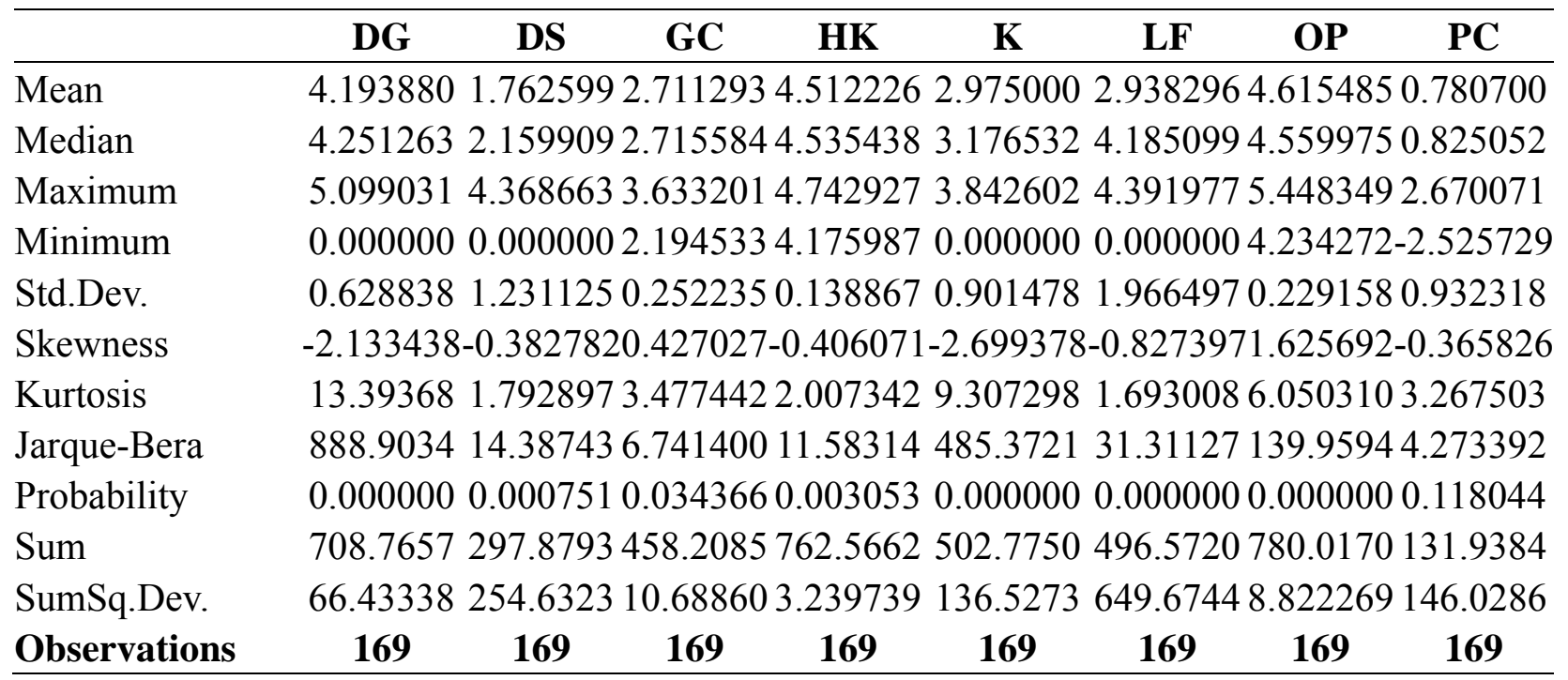

\section{Copyright Disclaimer}

Copyright reserved by the author(s).

This article is an open-access article distributed under the terms and conditions of the Creative Commons Attribution license (http://creativecommons.org/licenses/by/3.0/). 